\title{
Novel approaches to Pyranuronic $\beta$-Sugar Amino Acid building blocks of peptidosaccharide foldamers
}

Viktória Goldschmidt Gőz, ${ }^{[a]}$ István Pintér, ${ }^{[b]}$ Veronika Harmat, ${ }^{[a]}$ and András Percze ${ }^{*[a, b]}$

a V. Goldschmidt Gőz, Dr. V. Harmat and Prof. Dr. A. Perczel

MTA-ELTE Protein Modeling Research Group, 1117 Budapest, Pázmány Péter sétány 1/A, Hungary, e-mail: perczel@chem.elte.hu

b Dr. I. Pintér, Prof. Dr. A. Perczel

Laboratory of Structural Chemistry and Biology, Institute of Chemistry, Eötvös University, 1117

Budapest, Pázmány Péter sétány 1/A, Hungary

Keywords: Sugar amino acids, oxime reduction, foldamers, stereoselectivity, $\mathrm{H}$-bonding

\begin{abstract}
:
Pyranuronic $\beta$-S ugar amino acids, $\beta$-SAAs, are biocompatible and tuneable building blocks of foldamers and chimera-peptides. The scalable and economic total synthesis of two Lego-elements is described here. These C-4 epimers, Fmoc-GlcAPU(Me)-OH (7) and Fmoc-GalAPU(Me)-OH (8), suitable for solid phase peptide synthesis are prepared via a common oxime intermediate (16). The new process accomplished in nine consecutive steps starts from methyl-a-D-glucopyranoside (6) is fine-tuned, optimized and ready for large-scale and cost-efficient production.
\end{abstract}




\section{Introduction}

The excellent compendiums of Risseeuw et $a^{[1]}$ emphasizes the significance of natural and functionalized sugar amino acids (SAAs) in inter- and intracellular events of living organisms during the formation of glycomimetics, peptidomimetics, etc.. Nowadays, SAAs are widely used in the design and synthesis of foldamers ${ }^{2}$ as they have i) versatile nature, ii) tunable properties in terms of ring-size, stereochemistry, substituents, conformation, iii) adjustable hydrophilic / hydrophobic character as function of the free / protected $\mathrm{OH}$-groups. The oligomers of these building blocks are biocompatible and biodegradable though could resist against proteolytic enzymes. Homo- and hetero-oligomers made from solid phase peptide synthesis (SPPS), comprising the above building blocks could form different secondary structural elements and designed backbone scaffolds similarly to those occurring in polypeptides and proteins, but of different dynamic properties. ${ }^{[3-7]}$

\section{Results and Discussion}

Among the large numbers of cyclic SAAs composed of $\alpha$ - to $\varepsilon$-amino acid residues, mainly those of furanoid or pyranoid rings were described. The number of furanoid SAAs so far termed is way over 200, most of different kinds, ${ }^{[1]}$ while those forming pyranoid ring are significantly fewer, perhaps $<100$. This difference is even more significant when comparing $\beta$-SAAs: while more than 6 dozens of furanoid $\beta$ SAAs are known, ${ }^{[1]}$ the related pyranoid derivatives are about 10 . These ones are either similar to 2 amino-2-deoxy-glucopyranosyl carboxylic acids or to 4-amino-4-deoxy-D-glucopyranuronic acids. ${ }^{[1]}$ Thus, mostly the uronic acid derivatives of the furanoid ring containing $\alpha-, \beta$ - or $\delta$-SAAs were synthesized. As building blocks unavailable, the corresponding pyranoid SAAs are seldom used to make foldamers, focusing on the easily available D-glucosamine carboxylic acids. ${ }^{[4,8]}$

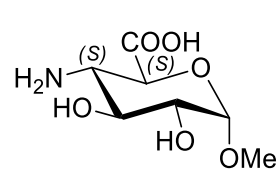

1, H-GIcAPU(Me)-OH

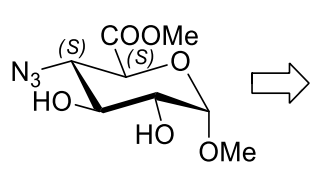

3

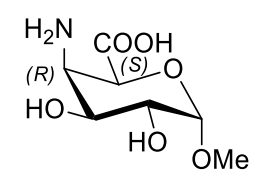

2, H-GalAPU(Me)-OH

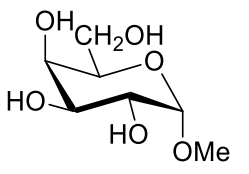

5
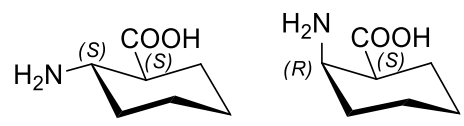

trans-(S,S)-ACHC cis-(S,R)-ACHC

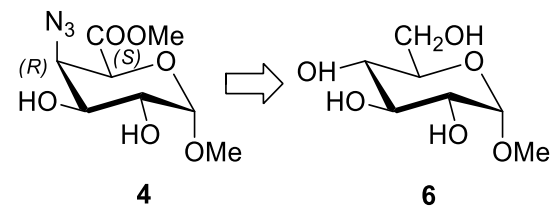

Figure 1. Molecular structure of our target SAAs (1, 2, unprotected OHs) with their precursors (3, 4) ${ }^{[15,16 i}$ and their carbocyclic analogues $(\mathrm{ACHC})$

Concerning peptidomimetics and glycomimetics derived from $\alpha$-AAs, acyclic or cyclic $\beta$-AAs (e.g. $A C P C{ }^{[9,10]}$ and $\mathrm{ACHC}^{[11,12]}$ ) and $\beta$-SAAs, we have completed the synthesis of selected 3-amino-3deoxy-pentofuranuronic acids ${ }^{[13]}$ and studied their coupling potential to form peptido-saccharides ${ }^{[14]}$ In a comparative context, our interest turned towards the hydrophilic version of the well-known foldamer building blocks (ACHC) as shown in Figure 1, namely the methyl 4-amino-4-deoxy- $\alpha$-Dglucopyranuronic (H-GlcAPU(Me)-OH, 1) and methyl 4-amino-4-deoxy-a-D-galactopyranuronic acids 
(H-GalAPU(Me)-OH, 2). Their derivatives (3 and 4) though partly described ${ }^{[15-17]}$ earlier, however, they never were considered as building blocks for foldamers.

The synthesis of these two $\beta$-SAAs of opposite C-4-configuration was described via two very different synthetic pathways: the D-gluco epimer ${ }^{[15]}$ (3) from methyl- $\alpha$-D-galactopyranoside (5), while the Dgalacto epimer ${ }^{[16]}$ (4) from methyl-a-D-glucopyranoside (6). The reason of the two fully detached pathways is that, in both cases the amino function was introduced with the usual sulfonate $\rightarrow$ azide nucleophilic substitution method. Carboxylic functions of both products were formed with the oxidation of the terminal $-\mathrm{CH}_{2} \mathrm{OH}$ groups. The first route involves nine, the second one as many as thirteen consecutive steps with overall yields of $39 \%$ and $5 \%$, respectively. In addition, both protocols are rather costly by using pricy reagents and materials (e.g. methyl- $\alpha$-D-galactopyranoside, $\mathrm{Tf}_{2} \mathrm{O}, \mathrm{NaCNBH}_{3}$ ). Additionally, column chromatography was needed to purify each of the intermediates of several synthetic steps, making the overall reaction routes environmentally unfriendly and hard to scale up. All these conditions forecast serious drawbacks in multigram production. Moreover, with a free amino group and with a protected carboxylic group both molecules ( $\mathbf{3}$ and $\mathbf{4})$ are unsuitable for SPPS. To turn them into suitable intermediates, two additional steps are to be implemented to make both of the appropriately N-protected SAAs: both Fmoc-GlcAPU(Me)-OH (7) and Fmoc-GalAPU(Me)-OH (8).

Thus, we have taken a conceptually new and economic approach to make both SAAs ( 7 and 8 ) from a common precursor. First, the methyl $\alpha$-D-glucopyranoside (6) was converted into methyl 2,3-di-Obenzyl-a-D-glucopyranoside (11), the key intermediate, and subsequently transformed into both amino derivatives (14 and 17) in two parallel pathways. In the other case, $\mathbf{1 1}$ was transformed into the oxime key intermediate (16) from which the two amino epimers were made following the same reaction protocol. Separation of these two epimers was achieved after transformation to Fmoc N-protected derivatives during the next step.

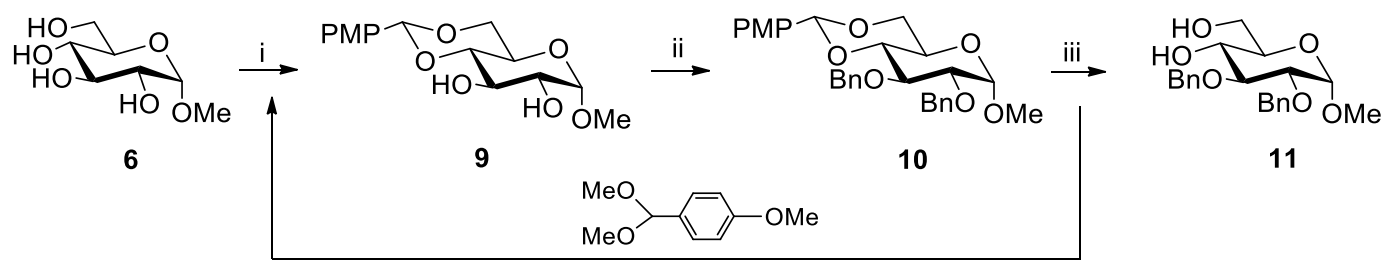

Scheme 1. Preparation of the benzylated common intermediate (11). Reagents and conditions: $l)$ anisaldehyde dimethyl acetal, CSA, DMF, $60^{\circ} \mathrm{C}, 1 \mathrm{~h}, 98 \%$; ii) $\mathrm{BnBr}, \mathrm{NaH}, \mathrm{DMF}, \mathrm{rt}, 1 \mathrm{~h}, 89 \%$; iii) $\mathrm{KHSO}_{4} \cdot \mathrm{H}_{2} \mathrm{O}, \mathrm{MeOH}, \mathrm{rt}, 1 \mathrm{~h}, 98 \%$.

In the first step from methyl-a-D-glucopyranoside (6) the 4,6-anisilidene derivative (9) was made. Both OHs of C-2 and C-3 carbon atoms were protected by benzylation ${ }^{[18]}(\mathbf{1 0})$, and then the 4,6deprotection ${ }^{[19]}$ was completed to produce the suitably protected diol (11) as white crystals in an overall yield of $85 \%$ (Scheme 1). We have considerably improved the efficiency by recovering $98 \%$ of the anisaldehyde dimethyl acetal. This modification resulted in a gainful recycling of the valuable reagent and in addition omitting column chromatography ${ }^{[19]}$ saving both time and a lot of organic solvent.

To form the amino group, we have selected two possible precursors as shown in Scheme 2. For route A, to get the D-galacto epimer (14) an oxazine ring (13) was introduced. ${ }^{[20]}$ In a one-pot reaction diol 11 was converted to the 6,4-(trichloro-oxazine) derivative (13). After chromatography, the ring was opened with $80 \%$ aqueous $\mathrm{AcOH}$ to give 14 in a good yield. On the other hand, to produce the D-gluco epimer (17) (route B) a new oxime (16) intermediate was synthesized. For that the required keto compound 
(15b) was formed via a stannylene derivative ${ }^{[21]}$ (15a) afterward it was converted to the oxime. Crude 16 was crystallized from ether-hexane, resulting in a key intermediate, reduced under $\mathrm{N}_{2}$ atmosphere with $\mathrm{LiAlH}_{4}$ providing 17 in $57 \%$ yield.

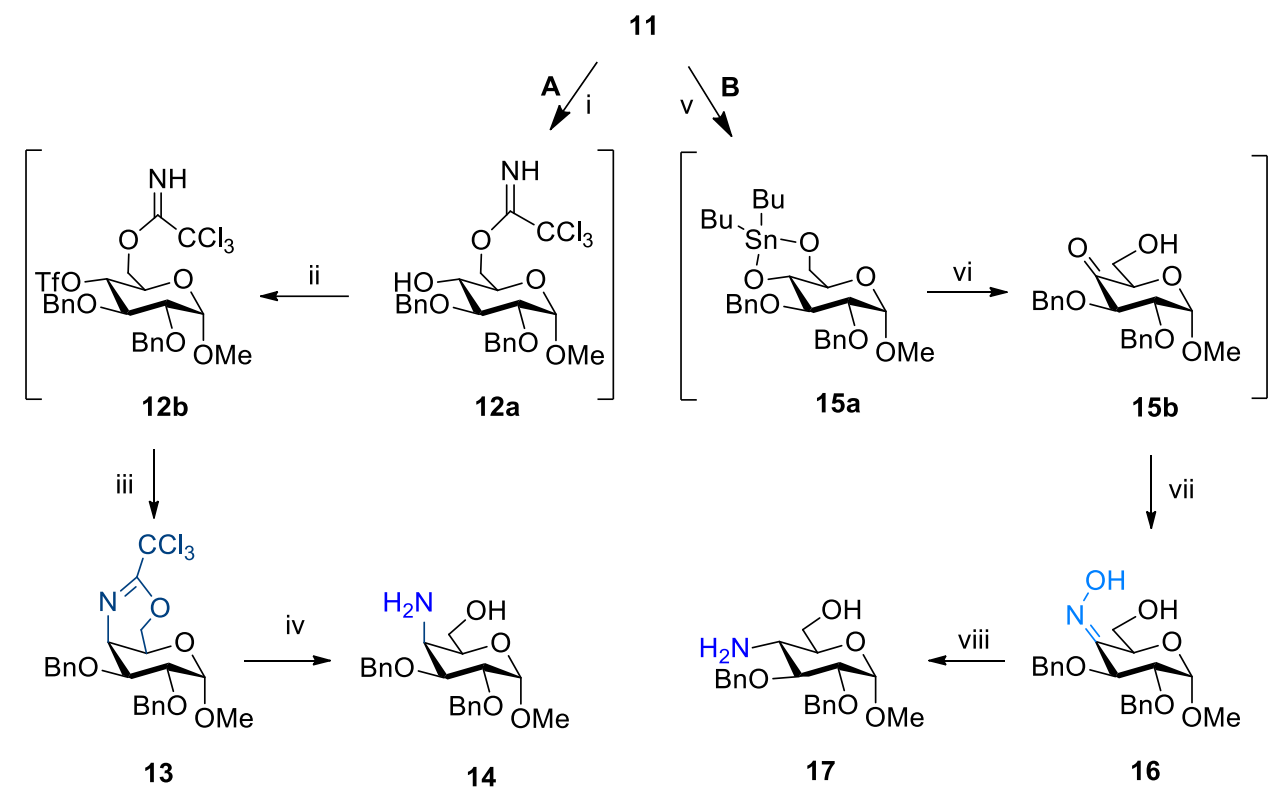

Scheme 2. New amino group introductions into C-4: A) selective oxazine ring opening to D-galacto epimer (14); B) selective oxime reduction to D-gluco epimer (17). Reagents and conditions: i) $\mathrm{Cl}_{3} \mathrm{CCN}$, DBU, DCM, $0^{\circ} \mathrm{C}, 5 \mathrm{~min}$; ii) $\mathrm{Tf}_{2} \mathrm{O}, \mathrm{Py}, 0^{\circ} \mathrm{C}, 5 \mathrm{~min}$; iii) DIPEA, rt, $3.5 \mathrm{~h}$, overall yield $69 \%$; iv) $80 \% \mathrm{AcOH}$, rt, $30 \mathrm{~min}, 80 \%$; v) $\mathrm{Bu}_{2} \mathrm{SnO}$, toluene, reflux, $12 \mathrm{~h}$; vi) 1,3-dibromo-5,5-dimethylhydantoin (DBDMH), $\mathrm{CHCl}_{3}$, rt, 15 min; vii) $\mathrm{NH}_{2} \mathrm{OH} . \mathrm{HCl}, \mathrm{NaOAc} .3 \mathrm{H}_{2} \mathrm{O}, \mathrm{AcOH}, 60^{\circ} \mathrm{C}, 5 \mathrm{~h}$, overall yield $62 \%$; viii) $\mathrm{LAH}, \mathrm{Et}_{2} \mathrm{O}$, rt, $24 \mathrm{~h}, 57 \%$.

Generally, selective reduction methods are applied in modern chemistry due to better yields and simple purification methods. ${ }^{[22,23]}$ However, in some cases non selective approaches are more economical, especially, if both epimers are needed. Route B via the oxime intermediate (16) opened a new and reasonable synthetic option, namely, to perform a non-selective oxime reduction furnishing both 14 and 17, eventually, in different ratio. Several reduction protocols were attempted (Table 1 in Supporting Information), however, successful reaction was achieved only in acidic medium. This was supported by the failure of the reduction with $\mathrm{NaBH}(\mathrm{OAc})_{3}$ in ${ }^{\mathrm{i}} \mathrm{PrOH}$. However, using $\mathrm{NaBH}_{4}$ in glacial acetic acid in situ forming $\mathrm{NaBH}(\mathrm{OAc})_{3}$ reduced the oxime to 4-deoxy-4-hydroxylamine epimers (18+19). Successively, the mixture of $\mathbf{1 8}$ and $\mathbf{1 9}$ was reduced in an $\mathrm{H}$-Cube reactor with $\mathrm{RaNi}$ catalyst in methanol (Scheme 3). This new method resulted in both 4-amino-4-deoxy epimers (14+17) in a 1:1 ratio confirmed by ${ }^{1} \mathrm{H}-\mathrm{NMR}$ spectra. Products were isolated in an excellent overall yield of $93 \%$. 


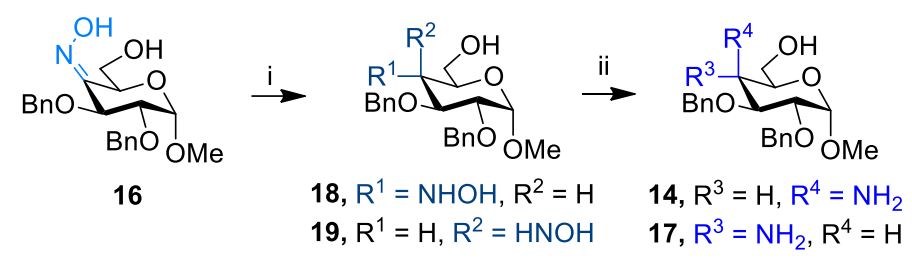

Scheme 3. The new non-selective reduction of the key oxime intermediate (16) in two steps. Reagents and conditions: i) $\mathrm{AcOH}, \mathrm{NaBH}_{4}$, rt, $1 \mathrm{~h}, 98 \%$; ii) $\mathrm{H}$-cube: $80^{\circ} \mathrm{C}, 50$ bar, RaNi catalyst, $97 \%$.

To explain the different stereoselectivity of the oxime reductions with $\mathrm{LiAlH}_{4}$ in $\mathrm{Et}_{2} \mathrm{O}$ or with $\mathrm{NaBH}_{4}$ in $\mathrm{AcOH}$, we are proposing here two mechanisms (Figure 2). In the case of $\mathrm{LiAlH}_{4}$ (a), oxime 16 can form a four-centered $\mathrm{C}=\mathrm{N}^{+} \ldots \mathrm{Al}-\mathrm{-H}$ complex in which the bulky $\left[\mathrm{AlH}_{4}\right]^{-}$ion can be attached only upper side to the pyranoid ring. The result is the stereoselective formation of the D-gluco epimer (17). The crystal structure of Z-oxime determined by X-ray diffraction method shows the pyranoid ring conformation and that the bulky substituents cause steric crowding only on the upper side of the plane of the oxime group, supporting the proposed mechanism for stereoselectivity (Figure $2 a$ and Supporting Information).
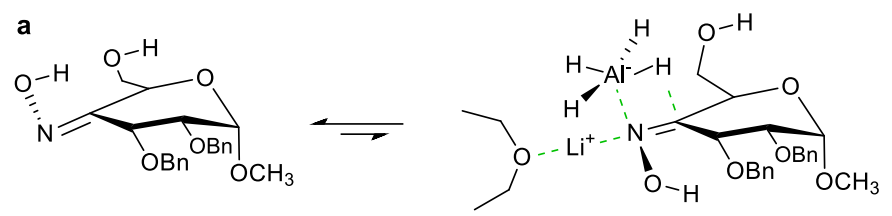

b

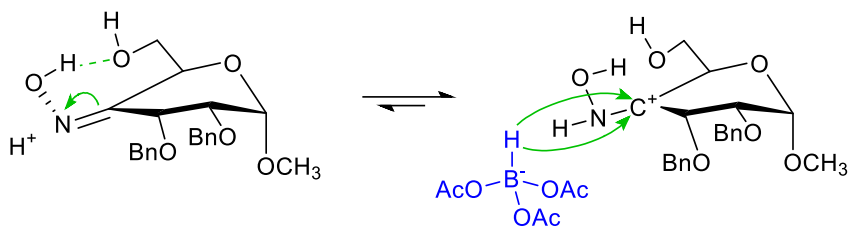

Figure 2. Proposed mechanism of the oxime (16) reduction with (a) $\mathrm{LiAlH}_{4}$ in $\mathrm{Et}_{2} \mathrm{O}$ and (b) with $\mathrm{NaBH}_{4}$ in $\mathrm{AcOH}$.

On the other hand, in acidic media the non-selective reduction is caused by the fast protonation of the oxime $\left(\mathrm{HN}^{+}-\mathrm{OH}\right)$ resulting in a "carbocation", which can be attacked by the $\mathrm{H}^{-}$anion from both sides of the molecule giving the hydroxylamine epimers $(\mathbf{1 8 + 1 9 )}$ in a 1:1 ratio (Figure 2b). This "carbocation" might be stabilized by a $-\mathrm{C}=\mathrm{N}-\mathrm{OH} . . \mathrm{O}$ - interaction between the oxime $\mathrm{OH}$ and the primary $\mathrm{OH}-6$. The existence of this in solution was unambiguously corroborated for both isomers by ${ }^{1} \mathrm{H}-{ }^{1} \mathrm{H}$ NOESY spectrum of the oxime (16). This exhibits a strong cross peak between $\mathrm{N}-\mathrm{OH}(9.13 \mathrm{ppm})$ and $\mathrm{OH}-6$ (2.72 ppm) of the $\boldsymbol{E}$-oxime (Figure 3 ). The ${ }^{1} \mathrm{H}$ NMR spectrum also reveals both $\boldsymbol{E}$ - and $\boldsymbol{Z}$-oximes in solution in a 93:7 ratio. 

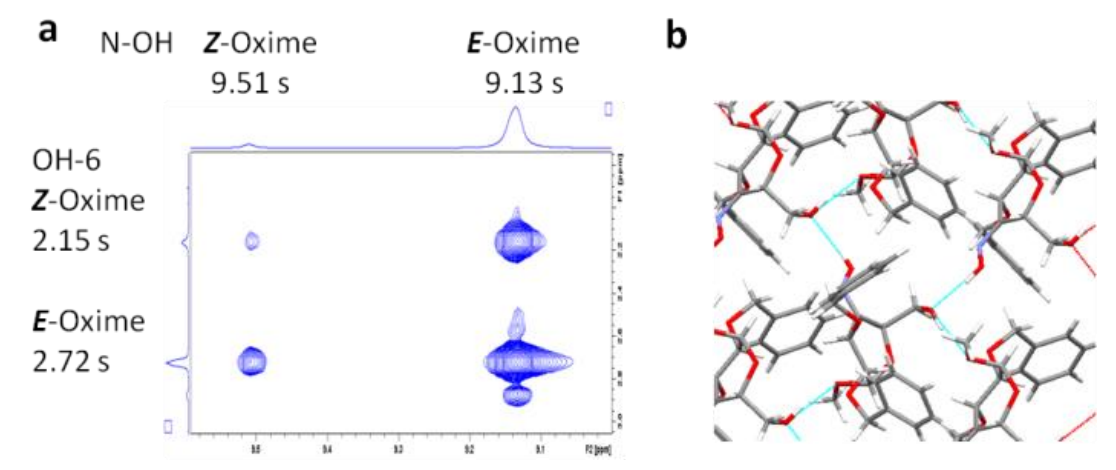

Figure 3. a) ${ }^{1} \mathrm{H}-{ }^{1} \mathrm{H}$ NOESY spectrum of oxime (16) shows NOESY cross peaks between the oxime $\mathrm{OHs}$ and the primary $\mathrm{OH}-6 \mathrm{~s}$; b) 3D crystal structure of the Z-oxime shows the intermolecular $\mathrm{H}$-bond network.

We notice here that crystal structure of 16 shows a definite intermolecular O-H..O-H bridge between the oxime $\mathrm{OH}$ and the primary $\mathrm{OH}-6$ of another vicinal oxime molecule shown by cyan colored lines (Figure $3 b$ ). This arrangement appearing in solution might ease the external protonation of the $-\mathrm{N}=\mathrm{O}$ moiety in $\mathbf{1 6}$ forming the "carbocation" in the case of the Z-oxime, too.

To conclude, the amino group of both D-gluco (14) and D-galacto (17) epimers was N-protected with Fmoc group, the primary choice when using SPPS. At this step the two C-4 epimers were separated due to their very different solubility in $\mathrm{Et}_{2} \mathrm{O}$. Trituration of the mixture yields the D-gluco epimer (20) as a white crystal, while the mother liquor treated with hexane results in the D-galacto epimer (21) as white oil. The carboxylic function was introduced by using TEMPO- $\mathrm{NaOCl}$ oxidation ${ }^{[24]}$ of the $\mathrm{CH}_{2} \mathrm{OH}$ group. Both carboxyl products were obtained in an excellent yield: $97 \%$ for the D-gluco (7) and $85 \%$ for the D-galacto epimer (8), respectively (Scheme 4).

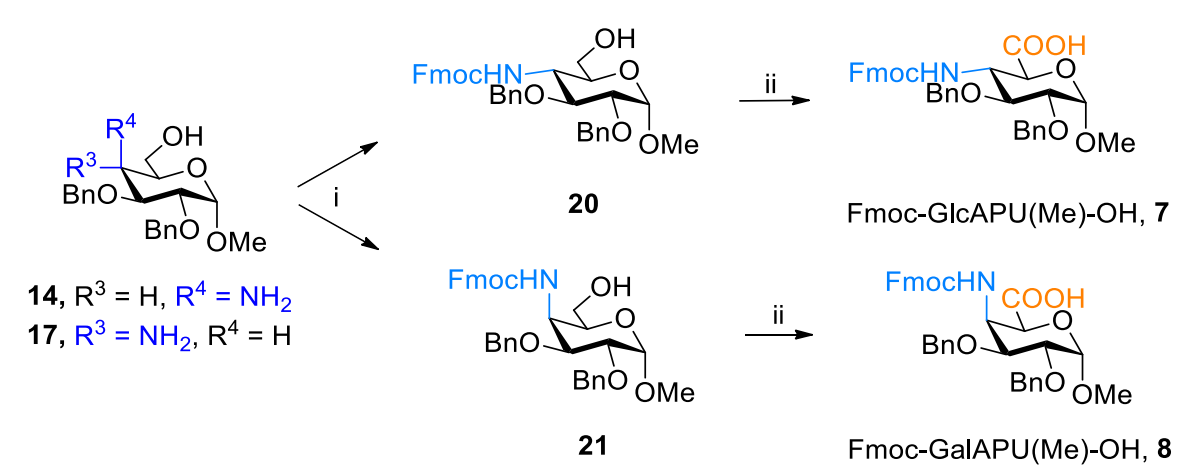

Scheme 4. Separation of the two epimers and final oxidation resulting both target $\beta$-SAAs $(7,8)$. $ו)$ FmocOSu, THF, MeOH: water 2:1, $\mathrm{NaHCO}_{3}$, rt, $24 \mathrm{~h}, 96 \%$ of $20,75 \%$ of 21 ; ii) TEMPO-NaOCl, $\mathrm{KBr}$, DCM, $0^{\circ} \mathrm{C}, 2 \mathrm{~h}, 96 \%$ of 7 and $85 \%$ of 8 .

These $\beta$-SAAs $(\mathbf{7}, \mathbf{8})$ are now appropriate for coupling with SPPS, as i) they are now available in multigram-scale; ii) products are soluble and stable in aprotic solvents; iii) their amino groups are Fmoc-protected while the $\mathrm{OH}$-groups still benzylated, iv) with a C-terminus - $\mathrm{COOH}$ easy to activate. 
The active ester formation of both diastereoisomers with different coupling reagents were tested and found to be stable enough during even longer coupling times (e.g. 24 hours).

\section{Conclusions}

In conclusion, economic and reasonable pathways were developed to synthesize two new $\beta$-sugar amino acids, namely, Fmoc-GlcAPU(Me)-OH (7) and Fmoc-GalAPU(Me)-OH (8). The new protocol uses only a single starting compound (6) and gives both targeted $\beta$-SAAs in good yields. By introducing the common key intermediate 16 we opened a new synthetic route to synthesize both of the C-4 epimers (14 and 17): the protected 4-amino-4-deoxy-D-gluco- and D-galactopyranoside. The non-selective reduction of the new oxime (16) gives a mixture of both C-4 epimers in two steps. Separation of them was easily performed afterwards. Additional benefits of this new protocol are as follows: i) the column chromatography was omitted at all steps; ii) the valuable anisaldehyde dimethyl acetal reagent was almost totally recycled (98\%). The scalable synthetic process resulted in FmocGlcAPU(Me)-OH (7) and Fmoc-GalAPU(Me)-OH (8) in an overall yield of $46 \%$ and $32 \%$, respectively. These $\beta$-SAAs are ready to be used as Lego-elements for SPPS, to make succesfully both homo- and heterofoldamers.

\section{Acknowledgements}

This work was supported by the VEKOP grants (VEKOP-2.3.2-16-2017-00014 and VEKOP-2.3.3-152017-00018) of NKFIH and MedInProt Grant Facilitating Access to Instruments of the Hungarian Academy of Sciences. Authors express their gratitude to Ágnes Gömöry at the Hungarian Academy of Science, Research Centre for Natural Sciences and Anita Kapros for performing the MS measurements. The authors wish to thank ThalesNano Inc. (Budapest, Hungary) for the H-Cube ${ }^{\circledR}$ equipment. The Biostruct Laboratory at the Budapest University of Technology and Economics is acknowledged for collecting X-ray diffraction data. The authors thank lbolya Leveles for her assistance in X-ray diffraction data collection. 


\section{Experimental Section}

General information, ${ }^{1} \mathrm{H}$ and ${ }^{13} \mathrm{C}$ NMR spectra, Tables and X-ray data for $\mathbf{1 6}$ can be found in Supporting Information, in the online version.

\section{Methyl 4,6-O-(4'-methoxybenzylidine)- $\alpha$-D-glucopyranoside (9)}

In a round-bottom flask methyl $\alpha$-D-glucopyranoside $(6,40 \mathrm{~g}, 0.2 \mathrm{~mol})$, camphor sulphonic acid $(0.46 \mathrm{~g}$, $2 \mathrm{mmol}$ ) and anisaldehyde dimethyl acetal $(41.3 \mathrm{ml}, 0.22 \mathrm{~mol})$ was mixed with dry DMF (160 ml). The mixture was heated under vacuum at $60{ }^{\circ} \mathrm{C}$ to remove the methanol. After 1 hour the temperature was raised to $65^{\circ} \mathrm{C}$ and the solvent was evaporated. The residual yellowish oil was poured into the mixture of ice $(100 \mathrm{~g})$, saturated aqueous $\mathrm{NaHCO}_{3}(200 \mathrm{ml})$ and ether $(200 \mathrm{ml})$. The product was filtered then washed with petrolether and water to give a white solid $(61.3 \mathrm{~g}, 95 \%) . R_{\mathrm{f}}=0.67$ (EtOAc/methanol 9:1); mp. $194^{\circ} \mathrm{C}, \mathrm{mp}_{\text {lit }}^{25} .194^{\circ} \mathrm{C}$.

\section{Methyl 2,3-di-O-benzyl-4,6-O-(4'-methoxybenzylidine)-a-D-glucopyranoside (10)}

In a three-necked flask equipped with mechanical stirrer compound 9 (15 g, $0.048 \mathrm{~mol})$ was dissolved in dry DMF $(200 \mathrm{ml})$ under Argon at $0^{\circ} \mathrm{C}$. Then $\mathrm{NaH}$ in $60 \%$ mineral oil $(4.8 \mathrm{~g}, 0.12 \mathrm{~mol})$ was added and stirred at room temperature for 15 minutes, afterward $\mathrm{BnBr}(14 \mathrm{ml}, 0.12 \mathrm{~mol}$ ) was added drop wise into this mixture and stirred for 1 hour. Then methanol $(40 \mathrm{ml})$ was added and stirred for 30 minutes to stop the reaction. The mixture was pour into ice $(500 \mathrm{~g})$ and filtered. The residue white solid was crystallized from hot ethanol $(400 \mathrm{ml})$ to give white crystals of $10(21.1 \mathrm{~g}, 89 \%) . R_{\mathrm{f}}=0.65$ (EtOAc/toluol 1:3); $\mathrm{mp}$. $142^{\circ} \mathrm{C}, \mathrm{mp}_{\text {lit }}^{25}$. $143-144^{\circ} \mathrm{C}$.

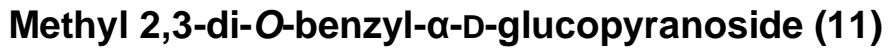

The synthesis of 11 was carried out from $10(26.3 \mathrm{~g}, 0.053 \mathrm{~mol})$ as described ${ }^{19}$ with differences in the purification, i.e. instead of column chromatography trituration of the crude product with petrolether gave the product as white powder $(21.2 \mathrm{~g}, 98 \%) . R_{\mathrm{f}}=0.18$ (EtOAc/petrolether $\left.1: 1\right)$; $\mathrm{mp} .73-75^{\circ} \mathrm{C}, \mathrm{mp}_{\text {lit }}^{26} .73-$ $75{ }^{\circ} \mathrm{C}$. For recycling the reagent the petrolether phase was concentrated resulting in the anisaldehyde dimethyl acetal in excellent yield $(9.7 \mathrm{ml}, 98 \%)$.

\section{Methyl 2,3-di-O-benzyl-a-D-xylopyranoside-4-ulose (15b)}

In a flask equipped with a Dean-Stark apparatus compound 11 (10 g, $0.026 \mathrm{~mol})$ was dissolved in toluene $(220 \mathrm{ml})$ and $\mathrm{Bu}_{2} \mathrm{SnO}(7.9 \mathrm{~g}, 0.032 \mathrm{~mol})$ was added and the mixture was refluxed for 11 hours, concentrated subsequently and dried in vacuo for 30 minutes. The residue was dissolved in chloroform $(220 \mathrm{ml})$ and DBDMH $(4.2 \mathrm{~g}, 0.014 \mathrm{~mol})$ was added in one portion and stirred until the mixture was discolored. It was filtered into $10 \% \mathrm{Na}_{2} \mathrm{~S}_{2} \mathrm{O}_{3}(150 \mathrm{ml})$ solution, the aqueous phase was separated and extracted with chloroform (100 ml). The combined organic phase was washed twice with water (100 $\mathrm{ml}$ ) and dried (sicc. $\left.\mathrm{MgSO}_{4}\right)$. After filtration and concentration yellow oil was obtained $(9.5 \mathrm{~g}) . R_{\mathrm{f}}=0.41$ (EtOAc/petrolether 1:1); IR $v=3462(\mathrm{OH}), 2956-2869(\mathrm{CH}), 1731(\mathrm{C}=\mathrm{O})$. The crude product was directly converted to oxime (16) without any purification. 
At first, NaOAc (10.9 g, $0.08 \mathrm{~mol})$ and hydroxylamine hydrochloride $(5.5 \mathrm{~g}, 0.08 \mathrm{~mol})$ was dissolved in acetic acid $(100 \mathrm{ml})$. The mixture was heated to $55^{\circ} \mathrm{C}$ and compound $15 \mathrm{~b}(9.9 \mathrm{~g}, 0.026 \mathrm{~mol})$ in acetic acid $(50 \mathrm{ml})$ was added. The solution was stirred under $\mathrm{N}_{2}$ for 6 hours at $55^{\circ} \mathrm{C}$. The mixture was poured into ice $(300 \mathrm{~g})$ and neutralized with saturated aqueous $\mathrm{Na}_{2} \mathrm{CO}_{3}$ solution, and then it was extracted with hexane twice $(2 \times 50 \mathrm{ml})$, then three times with EtOAc $(3 \times 100 \mathrm{ml})$. The hexane extract was discarded and the combined EtOAc phases were washed with saturated aqueous $\mathrm{Na}_{2} \mathrm{CO}_{3}$ and water $(100 \mathrm{ml})$. The organic phase was dried (sicc. $\mathrm{MgSO}_{4}$ ), filtered and concentrated in vacuo. The residue was solved in ether $(50 \mathrm{ml})$ and crystallized from hexane to give white crystals $(6.4 \mathrm{~g}, 62 \%) . R_{\mathrm{f}}=0.52$ (EtOAc/petrolether 1:1); mp. $91^{\circ} \mathrm{C} ;[\alpha]_{\mathrm{D}}{ }^{22}=+101.3,\left(c=1\right.$, chloroform); ${ }^{1} \mathbf{H}$ NMR $\left(\mathrm{CDCl}_{3}\right) \delta 9.13(\mathrm{~s}, 1 \mathrm{H}$, OH-oxime), 7.24-7.15 (m, BnO Ar-H), $4.96\left(\mathrm{dd},{ }^{3} \mathrm{~J}_{\mathrm{H}, \mathrm{H}}=5.3\right.$ and $\left.1.8 \mathrm{~Hz}, 1 \mathrm{H}, \mathrm{H}-5\right), 4.76\left(\mathrm{~d},{ }^{3} \mathrm{~J}, \mathrm{H}=3.7 \mathrm{~Hz}\right.$, $1 \mathrm{H}, \mathrm{H}-1), 4.53\left(\mathrm{~d},{ }^{3} \mathrm{~J}_{\mathrm{H}, \mathrm{H}}=11.6 \mathrm{~Hz}, 1 \mathrm{H}, \mathrm{BnO}-3: \mathrm{CH}_{2 \mathrm{~A}}\right), 4.51\left(\mathrm{~d},{ }^{3} \mathrm{~J}_{\mathrm{H}, \mathrm{H}}=12.1 \mathrm{~Hz}, 1 \mathrm{H}, \mathrm{BnO}-2: \mathrm{CH}_{2 \mathrm{~A}}\right), 4.45(\mathrm{~d}$, $\left.{ }^{3} J_{\mathrm{H}, \mathrm{H}}=12.1 \mathrm{~Hz}, 1 \mathrm{H}, \mathrm{BnO}-2: \mathrm{CH}_{2 \mathrm{~B}}\right), 4.28\left(\mathrm{~d},{ }^{3} \mathrm{~J}_{\mathrm{H}, \mathrm{H}}=11.6 \mathrm{~Hz}, 1 \mathrm{H}, \mathrm{BnO}-3: \mathrm{CH}_{2 \mathrm{~B}}\right), 4.06\left(\mathrm{~d},{ }^{3} \mathrm{~J}_{\mathrm{H}, \mathrm{H}}=3.4 \mathrm{~Hz}, 1 \mathrm{H}\right.$, $\mathrm{H}-3$ ), $3.86\left(\mathrm{dt},{ }^{3} \mathrm{~J}_{\mathrm{H}, \mathrm{H}}=11.5\right.$ and $5.0 \mathrm{~Hz}, 1 \mathrm{H}, \mathrm{H}-6_{\mathrm{A}}$ ), 3.78-3.74 (overlapped $\mathrm{m}, 1 \mathrm{H}, \mathrm{H}-6_{\mathrm{B}}$ ), 3.77 (overlapped $\left.\mathrm{t},{ }^{3} \mathrm{JH}_{\mathrm{H}, \mathrm{H}}=3.6 \mathrm{~Hz}, 1 \mathrm{H}, \mathrm{H}-2\right), 3.36\left(\mathrm{~s}, 3 \mathrm{H}, \mathrm{CH}_{3}\right), 2.72$ (very br t, $\left.1 \mathrm{H}, \mathrm{OH}-6\right) ;{ }^{13} \mathrm{C} \mathrm{NMR}\left(\mathrm{CDCl}_{3}\right) \delta 153.0(\mathrm{C}-4)$, 137.6 (BnO-3: C-1'), 137.1 (BnO-2: C-1'), 128.6, 128.5, 128.4 (BnO-3: C-2', C-3', C-4', C-5', C-6'), 128.2, 128.1, 128.0 (BnO-2: C-2', C-3', C-4', C-5', C-6'), 97.2 (C-1), 79.0 (C-2), 76.6 (C-3), 72.1 (BnO2: $\left.\mathrm{CH}_{2}{ }^{\prime}\right), 70.6\left(\mathrm{BnO}-3: \mathrm{CH}_{2}{ }^{\prime}\right), 68.5(\mathrm{C}-5), 62.1(\mathrm{C}-6), 56.6\left(\mathrm{CH}_{3}\right)$. HRMS m/z calculated for $\mathrm{C}_{21} \mathrm{H}_{26} \mathrm{NO}_{6}$ $\left[\mathrm{M}+\mathrm{H}^{+}\right]$388.1760, found: 388.1761 .

\section{Methyl 2,3-di-O-benzyl-4-deoxy-4-hydroxylamino-a-D-glucopyranoside (18) and methyl 2,3-di-O-

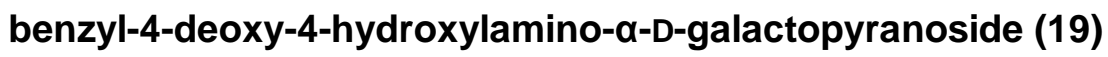

At first, $\mathrm{NaBH}_{4}(2.93 \mathrm{~g}, 0.077 \mathrm{~mol})$ was added in small portions to glacial acid $(50 \mathrm{ml})$ at $15-20{ }^{\circ} \mathrm{C}$. The mixture was stirred for $30 \mathrm{~min}$ then $16(5 \mathrm{~g}, 0.013 \mathrm{~mol})$ was added in one portion and stirred at room temperature for 2 hours. The reaction was treated with water $(10 \mathrm{ml})$ and neutralized with saturated aqueous $\mathrm{Na}_{2} \mathrm{CO}_{3}$. The mixture was extracted with dichloromethane twice $(2 \times 100 \mathrm{ml})$ and the combined organic phases were washed with saturated aqueous $\mathrm{Na}_{2} \mathrm{CO}_{3}\left(100 \mathrm{ml}\right.$ ), dried (sicc. $\mathrm{MgSO}_{4}$ ), filtered and concentrated in vacuo to give a colorless oil $\left(4.9 \mathrm{~g}, 98 \%\right.$ ). $R_{\mathrm{f}}=0.41$ and 0.46 (EtOAc/petrolether 1:1). The mixture of $\mathbf{1 8}$ and $\mathbf{1 9}$ was subsequently converted to the appropriate amine derivatives without prior separation.

\section{Methyl 2,3-di-O-benzyl-4-amino-4-deoxy-a-D-glucopyranoside (17) and methyl 2,3-di-O-benzyl-4-

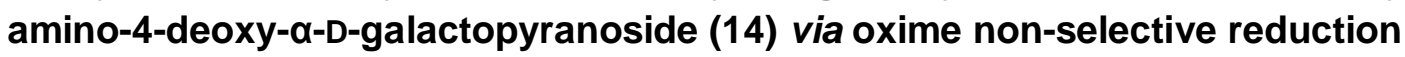

The mixture of 18 and 19 (4.8 g, $0.012 \mathrm{~mol})$ was dissolved in methanol $(620 \mathrm{ml})$ and was reduced in an $\mathrm{H}$-cube reactor: flow velocity set with an HPLC pump to $0.3 \mathrm{ml} / \mathrm{min}$. The hydrogen pressure was set to 50 bar, the temperature to $80{ }^{\circ} \mathrm{C}$ and a cartridge containing RaNi was utilized. Products were concentrated in vacuo to give a colorless oil (4.35 g, 97\%). The mixture of 14 and 179 was subsequently converted to the appropriate Fmoc derivatives without prior separation.

Compound 17: $R_{\mathrm{f}}=0.31\left(\mathrm{EtOAc} / \mathrm{methanol}^{9}: 1\right) ;{ }^{1} \mathrm{H}$ NMR $\left(\mathrm{CDCl}_{3}\right) \delta$ 7.28-7.16 (m, BnO Ar-H), 4.65 (overlapped d, ${ }^{3} \mathrm{~J}_{\mathrm{H}, \mathrm{H}}=11.5 \mathrm{~Hz}, 1 \mathrm{H}, \mathrm{BnO}-3: \mathrm{CH}_{2 \mathrm{~A}}$ ), 4.57 (overlapped d, ${ }^{3} \mathrm{~J}_{\mathrm{H}, \mathrm{H}}=11.5 \mathrm{~Hz}, 1 \mathrm{H}, \mathrm{BnO}-3: \mathrm{CH}_{2 \mathrm{~B}}$ ),

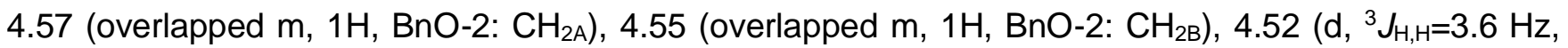
$1 \mathrm{H}, \mathrm{H}-1$ ), 3.63 (overlapped dd, ${ }^{3} \mathrm{~J}_{\mathrm{H}, \mathrm{H}}=6.3 \mathrm{~Hz}, 2 \mathrm{H}, \mathrm{H}-6_{\mathrm{A}}$ and $\mathrm{H}-6_{\mathrm{B}}$ ), $3.47\left(\mathrm{t},{ }^{3} \mathrm{~J}_{\mathrm{H}, \mathrm{H}}=9.5 \mathrm{~Hz}, 1 \mathrm{H}, \mathrm{H}-3\right.$ ), 3.41 (dd, ${ }^{3} J_{\mathrm{H}, \mathrm{H}}=9.7$ and $3.3 \mathrm{~Hz}, 1 \mathrm{H}, \mathrm{H}-2$ ), 3.36 (overlapped dd, $\left.{ }^{3} J_{\mathrm{H}, \mathrm{H}}=5.1 \mathrm{~Hz}, 1 \mathrm{H}, \mathrm{H}-5\right), 3.27\left(\mathrm{~s}, 3 \mathrm{H}, \mathrm{CH}_{3}\right)$, 
$2.60\left(\mathrm{t}, 1 \mathrm{H},{ }^{3} \mathrm{~J}_{\mathrm{H}, \mathrm{H}}=9.5 \mathrm{~Hz}, 1 \mathrm{H}, \mathrm{H}-4\right) 2.29$ (very br, $\left.1 \mathrm{H}, \mathrm{OH}-6\right) ;{ }^{13} \mathrm{C}$ NMR $\left(\mathrm{CDCl}_{3}\right) \delta 138.1,137.8,(\mathrm{BnO}-2$ : C-1'and BnO-3: C-1'), 128.03, 127.9, 127.3 (BnO-3: C-2', C-3', C-4', C-5', C-6'), 127.45, 127.41, 126.4 (BnO-2: C-2', C-3', C-4', C-5', C-6'), 97.7 (C-1), 81.4(C-3), 80.0 (C-2), 72.5 (BnO-2: $\left.\mathrm{CH}_{2}{ }^{\prime}\right), 72.0$ (BnO-3: $\left.\mathrm{CH}_{2}{ }^{\prime}\right), 70.4(\mathrm{C}-5), 62.9(\mathrm{C}-6), 54.8\left(\mathrm{CH}_{3}\right), 54.6(\mathrm{C}-4)$.

Compound 14: $R_{\mathrm{f}}=0.22$ (EtOAc/methanol 9:1); ${ }^{1} \mathrm{H}$ NMR $\left(\mathrm{CDCl}_{3}\right) \delta$ 7.28-7.16 (m, BnO-2 Ar-H, BnO-3 Ar-H), $4.95\left(\mathrm{~d},{ }^{3} \mathrm{~J}_{\mathrm{H}, \mathrm{H}}=11.4 \mathrm{~Hz}, 1 \mathrm{H}, \mathrm{BnO}-3: \mathrm{CH}_{2 \mathrm{~A}}\right.$ ), 4.71 (overlapped d, ${ }^{3} \mathrm{~J}_{\mathrm{H}, \mathrm{H}}=12.1 \mathrm{~Hz}, 1 \mathrm{H}, \mathrm{BnO}-2: \mathrm{CH}_{2 \mathrm{~A}}$ ), 4.64 (overlapped m, $1 \mathrm{H}, \mathrm{BnO}-2$ : $\mathrm{CH}_{2 \mathrm{~B}}$ ), 4.57 (overlapped d, ${ }^{3} \mathrm{~J}_{\mathrm{H}, \mathrm{H}}=11.4 \mathrm{~Hz}, 1 \mathrm{H}, \mathrm{BnO}-3$ : $\mathrm{CH}_{2 \mathrm{~B}}$ ), 4.57 (overlapped, $1 \mathrm{H}, \mathrm{H}-1$ ), 3.73 (overlapped t, ${ }^{3} \mathrm{~J}_{\mathrm{H}, \mathrm{H}}=5.6 \mathrm{~Hz}, 1 \mathrm{H}, \mathrm{H}-5$ ), 3.72 (overlapped t, ${ }^{3} \mathrm{~J}_{\mathrm{H}, \mathrm{H}}=5.2 \mathrm{~Hz}, 1 \mathrm{H}$,

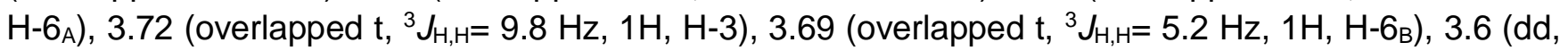
${ }^{3} \mathrm{~J}_{\mathrm{H}, \mathrm{H}}=6.4$ and $\left.3.7 \mathrm{~Hz}, 1 \mathrm{H}, \mathrm{H}-2\right), 3.27\left(\mathrm{~s}, 3 \mathrm{H}, \mathrm{CH}_{3}\right), 3.21\left(\mathrm{dd}, 1 \mathrm{H},{ }^{3} \mathrm{~J}_{\mathrm{H}, \mathrm{H}}=3.8 \mathrm{~Hz}, 1 \mathrm{H}, \mathrm{H}-4\right) 2.29(\mathrm{br}, 1 \mathrm{H}$, $\mathrm{OH}-6) ;{ }^{13} \mathrm{C}$ NMR $\left(\mathrm{CDCl}_{3}\right) \delta$ 137.9, 137.5, (BnO-2: C-1'and BnO-3: C-1'), 128.1, 128.06, 127.2 (BnO-3: C-2', C-3', C-4', C-5', C-6'), 127.6, 127.5, 126.9 (BnO-2: C-2', C-3', C-4', C-5', C-6'), 98.11 (C-1), 77.4 (C-5), 75.1 (BnO-3: $\left.\mathrm{CH}_{2}{ }^{\prime}\right), 75.0$ (C-2), $72.8\left(\mathrm{BnO}^{2}: \mathrm{CH}_{2}{ }^{\prime}\right), 68.1$, (C-3), $62.4(\mathrm{C}-6), 54.7\left(\mathrm{CH}_{3}\right), 51.1$ (C4).

\section{Methyl N-9-fluorenylmethoxycarbonyl-2,3-di-O-benzyl-4-amino-4-deoxy- $\alpha$-D-glucopyranoside (20) and methyl N-9-fluorenylmethoxycarbonyl-2,3-di-O-benzyl-4-amino-4-deoxy- $\alpha-D-$ galactopyranoside (21)}

The mixture of compounds 14 and $17(2.23 \mathrm{~g}, 6 \mathrm{mmol})$ were dissolved in a mixture of methanol:water 2:1 (48 $\mathrm{ml})$ and $\mathrm{pH}$ was adjusted to 9 with saturated aqueous $\mathrm{NaHCO}_{3}$, then Fmoc-OSu $(2.21 \mathrm{~g}, 6.53$ mmol) solution in THF (15 ml) was added and stirred for 24 hours, then the THF was evaporated and the residue was extracted twice with hexane $(2 x 50 \mathrm{ml})$ then three times with EtOAc $(3 \times 50 \mathrm{ml})$. The hexane extract was discarded while the combined EtOAc phases were washed with brine (100 ml), dried (sicc. $\mathrm{MgSO}_{4}$ ), filtered and concentrated in vacuo. The residue was treated with ether to give compound 20 as a white solid $(1.7 \mathrm{~g}, 96 \%), R_{\mathrm{f}}=0.15$ (ether/petrolether $\left.4: 1\right),[\alpha]_{\mathrm{D}}{ }^{22}=+28.3(\mathrm{c}=1$, chloroform); ${ }^{1} \mathrm{H}$ NMR $\left(\mathrm{CDCl}_{3}\right) \delta 7.68$ (dd, ${ }^{3} \mathrm{~J}_{\mathrm{H}, \mathrm{H}}=2.4$ and $7.2 \mathrm{~Hz}, 2 \mathrm{H}$, Fmoc-H-6, Fmoc-H-6'), 7.46 (dd, ${ }^{3} J_{\mathrm{H}, \mathrm{H}}=7.0$ and $3.0 \mathrm{~Hz}, 2 \mathrm{H}$, Fmoc-H-3, Fmoc-H-3'), 7.34-7.15 (m, BnO Ar-H, Fmoc-H-4, Fmoc-H-5, Fmoc-H-4', Fmoc-H-5'), $4.81\left(\mathrm{~d},{ }^{3} \mathrm{~J}_{\mathrm{H}, \mathrm{H}}=11.7 \mathrm{~Hz}, 1 \mathrm{H}, \mathrm{BnO}-3: \mathrm{CH}_{2 \mathrm{~A}}\right), 4.70\left(\mathrm{~d},{ }^{3} \mathrm{~J}_{\mathrm{H}, \mathrm{H}}=11.2 \mathrm{~Hz}, 1 \mathrm{H}, \mathrm{BnO}-2\right.$ : $\mathrm{CH}_{2 \mathrm{~A}}$ ), 4.58 (overlapped, $2 \mathrm{H}, \mathrm{BnO}-2: \mathrm{CH}_{2 \mathrm{~B}}, \mathrm{BnO}-3: \mathrm{CH}_{2 \mathrm{~B}}$ ), $4.53\left(\mathrm{~d},{ }^{3} \mathrm{~J}_{\mathrm{H}, \mathrm{H}}=3.3 \mathrm{~Hz}, 1 \mathrm{H}, \mathrm{H}-1\right.$ ), 4.48 (dd, ${ }^{3} J_{\mathrm{H}, \mathrm{H}}=10.7$ and $\left.4.2 \mathrm{~Hz}, 1 \mathrm{H}, \mathrm{Fmoc}-\mathrm{CH}_{2 \mathrm{~A}}\right), 4.36\left(\mathrm{dd},{ }^{3} \mathrm{~J}_{\mathrm{H}, \mathrm{H}}=10.7\right.$ and $\left.4.2 \mathrm{~Hz}, 1 \mathrm{H}, \mathrm{Fmoc}-\mathrm{CH}_{2 \mathrm{~b}}\right), 4.25$ (d, $\left.{ }^{3} J_{\mathrm{H}, \mathrm{H}}=6.9 \mathrm{~Hz}, 1 \mathrm{H}, \mathrm{NH}\right), 4.08\left(\mathrm{t},{ }^{3} \mathrm{~J}_{\mathrm{H}, \mathrm{H}}=6.1 \mathrm{~Hz}, 1 \mathrm{H}, \mathrm{Fmoc}-\mathrm{H}-1\right), 3.58$ (overlapped dd, ${ }^{3} \mathrm{~J}_{\mathrm{H}, \mathrm{H}}=9.8$ and 3.5 $\mathrm{Hz}, 1 \mathrm{H}, \mathrm{H}-4$ ), 3.57 (overlapped t, ${ }^{3} \mathrm{~J}_{\mathrm{H}, \mathrm{H}}=9.5 \mathrm{~Hz}, 1 \mathrm{H}, \mathrm{H}-3$ ), 3.52 (overlapped dd, ${ }^{3} \mathrm{~J}_{\mathrm{H}, \mathrm{H}}=8.8$ and $3.2 \mathrm{~Hz}$, $1 \mathrm{H}, \mathrm{H}-2), 3.46\left(\mathrm{dd},{ }^{3} \mathrm{~J}_{\mathrm{H}, \mathrm{H}}=12.7\right.$ and $\left.7.2 \mathrm{~Hz}, 1 \mathrm{H}, \mathrm{H}-6_{\mathrm{A}}\right), 3.40\left(\mathrm{dd},{ }^{3} \mathrm{~J}_{\mathrm{H}, \mathrm{H}}=12.7\right.$ and $\left.7.2 \mathrm{~Hz}, 1 \mathrm{H}, \mathrm{H}-6_{\mathrm{B}}\right), 3.25$ (overlapped s, $3 \mathrm{H}, \mathrm{CH}_{3}$ ), 3.25 (overlapped $\left.\mathrm{m}, 1 \mathrm{H}, \mathrm{H}-5\right) ;{ }^{13} \mathrm{C}$ NMR $\left(\mathrm{CDCl}_{3}\right) \delta 157.1$ (Fmoc-C=O), 143.9, 143.3 (Fmoc-C-2 and Fmoc-C-2'), 140.9 (Fmoc-C-7 and Fmoc-C-7'), 137.6 (BnO-3: C-1'), 137.3 (BnO-2: C-1'), 128.1, 128.0, (Fmoc-C-4 and Fmoc-C-4' and Fmoc-C-5 and Fmoc-C-5'), 127.9, 127.8, 127.6, 127.3 (BnO-3: C-2", C-3", C-4", C-5"' and, BnO-2: C-2', C-3', C-4', C-5'), 127.6 (BnO-3: C-6”'), 127.5 (BnO-2: C-6'), 124.4 (Fmoc-C-3 and Fmoc-C-3'), 119.6 (Fmoc-C-6 and Fmoc-C-6'), 97.8 (C-1),

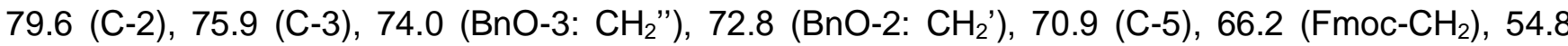
$\left(\mathrm{CH}_{3}\right), 51.4$ (C-4), 46.8 (Fmoc-C-1). HRMS m/z calculated for $\mathrm{C}_{36} \mathrm{H}_{38} \mathrm{NO}_{7}\left[\mathrm{M}+\mathrm{H}^{+}\right]$596.2648, found: 596.2631.

The mother liquor was concentrated and treated with hexane to give compound 21 as a white oil ( $1.3 \mathrm{~g}$, $75 \%) . R_{\mathrm{f}}=0.23$ (ether/petrolether 4:1). $[\alpha]_{\mathrm{D}}{ }^{22}=+44\left(\mathrm{c}=0.5\right.$, chloroform); ${ }^{1} \mathrm{H}$ NMR $\left(\mathrm{CDCl}_{3}\right) \delta 7.69\left(\mathrm{~d},{ }^{3} \mathrm{~J}_{\mathrm{H}, \mathrm{H}=}\right.$ $7.6 \mathrm{~Hz}, 2 \mathrm{H}$, Fmoc-H-6, Fmoc-H-6'), 7.50 (t, ${ }^{3} \mathrm{~J}_{\mathrm{H}, \mathrm{H}}=6.4 \mathrm{~Hz}, 2 \mathrm{H}$, Fmoc-H-4, Fmoc-H-4'), 7.33-7.17 (m, 14H, BnO-2 Ar-H, BnO-3 Ar-H, Fmoc-H-3, Fmoc-H-5, Fmoc-H-3', Fmoc-H-5'), 4.92 (d, ${ }^{3} J_{\mathrm{H}, \mathrm{H}}=8.5 \mathrm{~Hz}$, 
$1 \mathrm{H}, \mathrm{NH}$ ), $4.77\left(\mathrm{~d},{ }^{3} \mathrm{~J}_{\mathrm{H}, \mathrm{H}}=12.8 \mathrm{~Hz}, 1 \mathrm{H}, \mathrm{BnO}-3: \mathrm{CH}_{2 \mathrm{~A}}\right.$ ), 4.63 (overlapped d, ${ }^{3} \mathrm{~J}_{\mathrm{H}, \mathrm{H}}=12.8 \mathrm{~Hz}, 1 \mathrm{H}, \mathrm{BnO}-3$ : $\mathrm{CH}_{2 \mathrm{~B}}$ ), 4.62 (overlapped d, ${ }^{3} \mathrm{~J}_{\mathrm{H}, \mathrm{H}}=11.6 \mathrm{~Hz}, 2 \mathrm{H}, \mathrm{BnO}-2: \mathrm{CH}_{2 \mathrm{~A}}$ ), $4.53\left(\mathrm{~d},{ }^{3} \mathrm{~J}_{\mathrm{H}, \mathrm{H}}=3.5 \mathrm{~Hz}, 1 \mathrm{H}, \mathrm{H}-1\right), 4.50$ (d, $\left.{ }^{3} J_{\mathrm{H}, \mathrm{H}}=11.6 \mathrm{~Hz}, 1 \mathrm{H}, \mathrm{BnO}-2: \mathrm{CH}_{2 \mathrm{~B}}\right), 4.44\left(\mathrm{dd},{ }^{3} \mathrm{~J}_{\mathrm{H}, \mathrm{H}}=10.7\right.$ and $\left.6.5 \mathrm{~Hz}, 1 \mathrm{H}, \mathrm{Fmoc}-\mathrm{CH}_{2 \mathrm{~A}}\right), 4.38\left(\mathrm{dd},{ }^{3} \mathrm{~J}_{\mathrm{H}, \mathrm{H}=}\right.$ 10.7 and $\left.6.5 \mathrm{~Hz}, 1 \mathrm{H}, \mathrm{Fmoc}-\mathrm{CH}_{2 \mathrm{~b}}\right), 4.27\left(\mathrm{dd},{ }^{3} \mathrm{~J}_{\mathrm{H}, \mathrm{H}}=8.2\right.$ and $\left.4.9 \mathrm{~Hz}, 1 \mathrm{H}, \mathrm{H}-4\right), 4.13\left(\mathrm{t},{ }^{3} \mathrm{~J}_{\mathrm{H}, \mathrm{H}}=6.7 \mathrm{~Hz}, 1 \mathrm{H}\right.$, Fmoc-H-1), $3.94\left(\mathrm{dd},{ }^{3} \mathrm{~J}_{\mathrm{H}, \mathrm{H}}=9.9\right.$ and $\left.4.4 \mathrm{~Hz}, 1 \mathrm{H}, \mathrm{H}-5\right), 3.82\left(\mathrm{t},{ }^{3} \mathrm{~J}_{\mathrm{H}, \mathrm{H}}=6.9 \mathrm{~Hz}, 1 \mathrm{H}, \mathrm{H}-3\right), 3.45(\mathrm{~m}, 1 \mathrm{H}, \mathrm{H}-$ $\left.6_{\mathrm{A}}\right), 3.40\left(\mathrm{dd},{ }^{3} \mathrm{~J}_{\mathrm{H}, \mathrm{H}}=9.8\right.$ and $\left.3.3 \mathrm{~Hz}, 1 \mathrm{H}, \mathrm{H}-2\right), 3.35\left(\mathrm{~m}, 1 \mathrm{H}, \mathrm{H}-6_{\mathrm{B}}\right), 3.28\left(\mathrm{~s}, 3 \mathrm{H}, \mathrm{CH}_{3}\right), 3.03\left(\mathrm{brt},{ }^{3} \mathrm{~J}_{\mathrm{O}, \mathrm{H}}=\right.$ $5.4 \mathrm{~Hz}, 1 \mathrm{H}, \mathrm{OH}-6) ;{ }^{13} \mathrm{C}$ NMR $\left(\mathrm{CDCl}_{3}\right) \delta 158.0$ (Fmoc-C=O), 143.7, 143.4 (Fmoc-C-2 and Fmoc-C-2'), 141.3, 141.2 (Fmoc-C-7 and Fmoc-C-7'), 138.1 (BnO-3: C-1"), 137.8 (BnO-2: C-1'), 128.4, 128.3 (BnO-3: C-2", C-6", BnO-2: C-2', C-6'), 127.9, 127.8 (BnO-3: C-3", C-5", BnO-2: C-3', C-5'), 127.71, 127.70 (BnO-3: C-4", BnO-2: C-4'), 127.69, 127.94, 127.04, 127.02 (Fmoc-C-4 and Fmoc-C-4' and Fmoc-C-5 and Fmoc-C-5'), 124.9, 124.8 (Fmoc-C-3 and Fmoc-C-3'), 119.97, 119.95 (Fmoc-C-6 and Fmoc-C-6'), 98.3 (C-1), 75.5 (C-3), 75.3 (C-2), 73.5 (BnO-3: $\left.\mathrm{CH}_{2}{ }^{\prime \prime}\right), 71.4$ (BnO-2: $\left.\mathrm{CH}_{2}{ }^{\prime}\right), 68.5$ (C-5), $66.9\left(\mathrm{Fmoc}-\mathrm{CH}_{2}\right), 60.8$ (C-6), $55.4\left(\mathrm{CH}_{3}\right), 49.7$ (C-4), 47.2 (Fmoc-C-1). HRMS m/z calculated for $\mathrm{C}_{36} \mathrm{H}_{38} \mathrm{NO}_{7}\left[\mathrm{M}+\mathrm{H}^{+}\right]$596.2648, found: 596.2645.

\section{Methyl N-9-fluorenylmethoxycarbonyl-2,3-di-O-benzyl-4-amino-4-deoxy- $\alpha-D-g l u c o p y r a n o s i d e$ uronic acid (7)}

Compound 20 (2.36 g, $4 \mathrm{mmol}$ ) was dissolved in THF:saturated aqueous $\mathrm{NaHCO}_{3} 1: 1(96 \mathrm{ml})$ at $0^{\circ} \mathrm{C}$ and TEMPO (125 mg, $0.8 \mathrm{mmol})$ and $\mathrm{KBr}(141 \mathrm{mg}, 1.2 \mathrm{mmol})$ were added; to this mixture $0.47 \mathrm{M}$ $\mathrm{NaOCl}(17.6 \mathrm{ml})$ was added dropwise at $0^{\circ} \mathrm{C}$. After 1 hour an additional amounts of $\mathrm{NaOCl}(8 \mathrm{ml})$ and TEMPO $(60 \mathrm{mg})$ were added and stirred for another 1 hour at $0^{\circ} \mathrm{C}$. The solution was extracted with hexane twice $(2 \times 20 \mathrm{ml})$. The aqueous layer was acidified with saturated aqueous $\mathrm{NaHSO}_{4}$ to $\mathrm{pH} 3$ and extracted with EtOAc four times $(4 \times 50 \mathrm{ml})$. The hexane extracts were discarded while the combined EtOAc layers were dried (sicc. $\mathrm{MgSO}_{4}$ ), filtered and concentrated. The residue was treated with hexane $(30 \mathrm{ml})$ to give the desired product as white solids $(2.35 \mathrm{~g}, 97 \%) . R_{\mathrm{f}}=0.18$ (methanol/EtOAc/AcOH 9:1:0.01); mp. 158-160 ${ }^{\circ} \mathrm{C} ;[\alpha]_{\mathrm{D}}{ }^{22}=35.9$, (c=0.48, chloroform); ${ }^{1} \mathrm{H}$ NMR (DMSOd $\mathrm{d}_{6} \delta 7.88\left(\mathrm{~d},{ }^{3} \mathrm{~J}_{\mathrm{H}, \mathrm{H}}=7.5 \mathrm{~Hz}, 2 \mathrm{H}, \mathrm{Fmoc}-\mathrm{H}-6\right.$, Fmoc-H-6'), $7.70\left(\mathrm{dd},{ }^{3} \mathrm{~J}_{\mathrm{H}, \mathrm{H}}=7.4 \mathrm{~Hz}, 2 \mathrm{H}, \mathrm{Fmoc}-\mathrm{H}-3\right.$, Fmoc$\left.\mathrm{H}-3^{\prime}\right), 7.65\left(\mathrm{~d},{ }^{3} \mathrm{~J}_{\mathrm{H}, \mathrm{H}}=7.6 \mathrm{~Hz}, 1 \mathrm{H}, \mathrm{NH}\right), 7.40-7.18(\mathrm{~m}, 14 \mathrm{H}, \mathrm{BnO}$ Ar-H, Fmoc-H-4, Fmoc-H-5, Fmoc-H-4', Fmoc-H-5), $4.91\left(\mathrm{~d},{ }^{3} \mathrm{~J}_{\mathrm{H}, \mathrm{H}}=3.31 \mathrm{~Hz}, 1 \mathrm{H}, \mathrm{H}-1\right), 4.70\left(\mathrm{~d},{ }^{3} \mathrm{~J}_{\mathrm{H}, \mathrm{H}}=11.2 \mathrm{~Hz}, 1 \mathrm{H}, \mathrm{BnO}-3: \mathrm{CH}_{2 \mathrm{~A}}\right), 4.65$ (overlapped d, $\left.{ }^{3} \mathrm{~J}_{\mathrm{H}, \mathrm{H}}=12.04 \mathrm{~Hz}, 1 \mathrm{H}, \mathrm{BnO}-2: \mathrm{CH}_{2 \mathrm{~A}}\right), 4.64\left(\mathrm{~d},{ }^{3} \mathrm{~J}_{\mathrm{H}, \mathrm{H}}=11.8 \mathrm{~Hz}, 1 \mathrm{H}, \mathrm{BnO}-2: \mathrm{CH}_{2 \mathrm{~B}}\right), 4.55(\mathrm{~d}$, ${ }^{3} J_{\mathrm{H}, \mathrm{H}}=11.2 \mathrm{~Hz}, 1 \mathrm{H}, \mathrm{BnO}-3: \mathrm{CH}_{2 \mathrm{~B}}$ ), 4.26 (overlapped d, ${ }^{3} \mathrm{~J}_{\mathrm{H}, \mathrm{H}}=9.02 \mathrm{~Hz}, 1 \mathrm{H}$, ), 4.16 (overlapped d, ${ }^{3} J_{\mathrm{H}, \mathrm{H}}=$ $9.02 \mathrm{~Hz}, 1 \mathrm{H}, \mathrm{Fmoc}-\mathrm{CH}_{2 \mathrm{~A}}$ ), 4.14 (overlapped t, $1 \mathrm{H}, \mathrm{Fmoc}-\mathrm{H}-1$ ), $4.03\left(\mathrm{~d},{ }^{3} \mathrm{~J}_{\mathrm{H}, \mathrm{H}}=10.5 \mathrm{~Hz}, 1 \mathrm{H}, \mathrm{H}-5\right), 3.83$ (t, $\left.{ }^{3} J_{\mathrm{H}, \mathrm{H}}=9.7 \mathrm{~Hz}, 1 \mathrm{H}, \mathrm{H}-3\right), 3.69\left(\mathrm{dd},{ }^{3} \mathrm{~J}_{\mathrm{H}, \mathrm{H}}=10.1 \mathrm{~Hz}, 1 \mathrm{H}, \mathrm{H}-4\right), 3.51\left(\mathrm{dd},{ }^{3} \mathrm{~J}_{\mathrm{H}, \mathrm{H}}=9.5\right.$ and $\left.3.4 \mathrm{~Hz}, 1 \mathrm{H}, \mathrm{H}-2\right)$, $3.33\left(\mathrm{~s}, 3 \mathrm{H}, \mathrm{CH}_{3}\right) ;{ }^{13} \mathrm{C}$ NMR (DMSO-d 6$) \delta 169.9(\mathrm{COOH}-6), 155.7$ (Fmoc-C=O), 143.8, 143.7 (Fmoc-C2 and Fmoc-C-2'), 140.6 (Fmoc-C-7 and Fmoc-C-7'), 138.6 (BnO-3: C-1"), 138.4 (BnO-2: C-1'), 128.2, 127.9, 127.6, 127.5 (BnO-3: C-2", C-3", C-4", C-5", C-6"' and, BnO-2: C-2', C-3', C-4', C-5', C-6'), 127.2 (Fmoc-C-5 and Fmoc-C-5'), 127.0 (Fmoc-C-4 and Fmoc-C-4'), 125.3, 125.1 (Fmoc-C-3 and Fmoc-C-3'), 120.1 (Fmoc-C-6 and Fmoc-C-6'), 97.6 (C-1), 79.2 (C-3), 77.9 (C-2), 74.3 (BnO-3: $\mathrm{CH}_{2}{ }^{\prime}$ ),

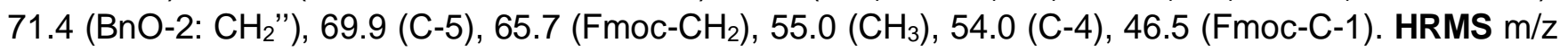
calculated for $\mathrm{C}_{36} \mathrm{H}_{36} \mathrm{NO}_{8}\left[\mathrm{M}+\mathrm{H}^{+}\right] 610.2441$, found: 610.2450 .

\section{Methyl N-9-fluorenylmethoxycarbonyl-2,3-di-O-benzyl-4-amino-4-deoxy- $\alpha-D-g a l a c t o p y r a n o s i d e$ uronic acid (8)}

Compound 8 was synthesized as described for 7 from $21(1.20 \mathrm{~g}, 2 \mathrm{mmol}): \mathbf{8}$ was isolated as a white powder $(1.04 \mathrm{~g}, 85 \%) . R_{\mathrm{f}}=0.38$ (methanol/EtOAc/AcOH 9:1:0.01); mp. $75-78{ }^{\circ} \mathrm{C} ;[\alpha]_{\mathrm{D}}{ }^{22}=+58.4,(\mathrm{c}=0.49$, 
chloroform); ${ }^{1} \mathbf{H}$ NMR (DMSO-d $) \delta 7.89\left(\mathrm{~d},{ }^{3} \mathrm{~J}_{\mathrm{H}, \mathrm{H}}=7.5 \mathrm{~Hz}, 2 \mathrm{H}\right.$, Fmoc-H-6,Fmoc-H-6'), 7.77 (dd, ${ }^{3} \mathrm{~J}_{\mathrm{H}, \mathrm{H}=}$ $7.4 \mathrm{~Hz}, 2 \mathrm{H}$, Fmoc-H-3, Fmoc-H-3'), $7.64\left(\mathrm{~d},{ }^{3} \mathrm{~J}_{\mathrm{H}, \mathrm{H}}=10.6 \mathrm{~Hz}, 1 \mathrm{H}, \mathrm{NH}\right), 7.44-7.18(\mathrm{~m}, 14 \mathrm{H}, \mathrm{BnO}$ Ar- $\mathrm{H}$, Fmoc-H-4, Fmoc-H-5, Fmoc-H-4', Fmoc-H-5'), 4.86 (d, ${ }^{3} J_{H, H}=5.31 \mathrm{~Hz}, 1 \mathrm{H}, \mathrm{H}-1$ ), 4.72 (overlapped d,

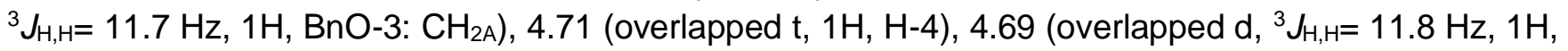
$\mathrm{BnO}-2: \mathrm{CH}_{2 \mathrm{~A}}$ ), 4.59 (d, $\left.{ }^{3} \mathrm{~J}_{\mathrm{H}, \mathrm{H}}=11.8 \mathrm{~Hz}, 1 \mathrm{H}, \mathrm{BnO}-2: \mathrm{CH}_{2 \mathrm{~B}}\right), 4.49\left(\mathrm{~d},{ }^{3} \mathrm{~J}_{\mathrm{H}, \mathrm{H}}=11.7 \mathrm{~Hz}, 1 \mathrm{H}, \mathrm{BnO}-3: \mathrm{CH}_{2 \mathrm{~B}}\right.$ ), $4.38\left(\mathrm{~d},{ }^{3} \mathrm{~J}_{\mathrm{H}, \mathrm{H}}=1.7 \mathrm{~Hz}, 1 \mathrm{H}, \mathrm{H}-5\right), 4.18$ (overlapped t, $1 \mathrm{H}, \mathrm{Fmoc}-\mathrm{H}-1$ ), 4.17 (overlapped m, 2H, Fmoc$\left.\mathrm{CH}_{2}\right), 4.0\left(\mathrm{dd},{ }^{3} \mathrm{JH}_{\mathrm{H}, \mathrm{H}}=10.4\right.$ and $\left.6.7 \mathrm{~Hz}, 1 \mathrm{H}, \mathrm{H}-3\right), 3.92\left(\mathrm{dd},{ }^{3} \mathrm{~J}_{\mathrm{H}, \mathrm{H}}=10.2\right.$ and $\left.5.9 \mathrm{~Hz}, 1 \mathrm{H}, \mathrm{H}-2\right), 3.30(\mathrm{~s}, 3 \mathrm{H}$, $\left.\mathrm{CH}_{3}\right) ;{ }^{13} \mathrm{C}$ NMR (DMSO-d 6 ) $\delta 169.1$ (COOH-6), 156.2 (Fmoc-C=O), 143.8, 143.7 (Fmoc-C-2 and FmocC-2'), 140.6 (Fmoc-C-7 and Fmoc-C-7'), 138.9 (BnO-3: C-1'), 138.6 (BnO-2: C-1'), 128.0, 127.9, 127.6, 127.3 (BnO-3: C-2", C-3", C-4", C-5", C-6" and, BnO-2: C-2', C-3', C-4', C-5', C-6'), 127.3 (Fmoc-C-5 and Fmoc-C-5'), 127.2 (Fmoc-C-4 and Fmoc-C-4'), 125.5 (Fmoc-C-3 and Fmoc-C-3'), 120.0 (Fmoc-C6 and Fmoc-C-6'), 98.2 (C-1), 75.4 (C-2), 74.8 (C-3), 71.8 (BnO-2: $\left.\mathrm{CH}_{2}{ }^{\prime}\right), 70.2$ (BnO-3: $\left.\mathrm{CH}_{2}{ }^{\prime \prime}\right), 68.3$ (C5), $65.8\left(\mathrm{Fmoc}-\mathrm{CH}_{2}\right), 50.5$ (C-4), 46.5 (Fmoc-C-1). HRMS m/z calculated for $\mathrm{C}_{36} \mathrm{H}_{36} \mathrm{NO}_{8}\left[\mathrm{M}+\mathrm{H}^{+}\right]$ 610.2441 , found: 610.2440 . 


\section{References}

[1] a) M.D.P. Risseeuw, M. Overhand, G.W.J. Fleet, M.I. Simone, Tetrahedron: Asymmetry 2007, 18, 2001; b) M.D.P. Risseeuw,; M. Overhand, G.W.J. Fleet, M.I. Simone, Amino Acids 2013, 45, 613.

[2] S.H. Gellman, Acc. Chem. Res. 1998, 31, 173.

[3] S.A.W. Gruner, V. Truffault, G. Voll, E. Locardi, M. Stöckle, H. Kessler, Chem. Eur. J. 2002, 8, 4365.

[4] a) Y. Suhara, Y. Yamaguchi, B. Collins, R.L. Schnaar, M. Yanagishita, J.E.K. Hildreth, I. Shimada, Y. Ichikawa, Bioorg. Med. Chem. 2002, 10, 1999. b) Y. Suhara, M. Kurihara, A. Kittaka, Y. Ichikawa, Tetrahedron, 2006, 62, 8207.

[5] S. Chandrasekhar, M.S. Reddy, B. Jagadeesh, A. Prabhakar, M.H.V.R. Rao, B. Jagannadh, J. Am. Chem. Soc. 2004, 126, 13586.

[6] A.A. Edwards, B.D. Alexander, G.W.J. Fleet, G. Tranter, Chirality 2008, 20, 969.

[7] A.D. Knijnenburg, A.W. Tuin, E. Spalburg, A.J. de Neeling, R.H. Mars-Groenendijk, D. Noort, J.M. Otero, A.L. Llamas-Saiz, M.J. van Raaij, G.A. van der Marel, H.S. Overkleeft, M. Overhand, Chem. Eur. J. 2011, 17, 3995.

[8] a) T. Hirata, F. Fujimura, Y. Horikawa, J. Sugiyama, T. Morita, S. Kimura, Peptide Science 2007, 88, 150. b) Y. Ishihara, S. Kimura, Peptide Science 2013, 100, 141.

[9] D.H. Apella, L.A. Christianson, D.A. Klein, D.R. Powell, X. Huang, J.J. Barchi Jr, S.H. Gellman, Nature, 1997, 387, 381.

[10] S.K. Pandey, G.F. Jogdand, J.C.A. Oliveira, R.A. Mata, P.R. Rajamohanan, C.V. Ramana, Chem. Eur. J. 2011, 17, 12946.

[11] I.M. Mándity, L.; Fülöp, E. Vass, G.K. Tóth, T.A. Martinek, F. Fülöp, Org. Lett. 2010, 12, 5584.

[12] T.A. Martinek, F. Fülöp, Chem. Soc. Rev. 2012, 41, 687.

[13]A. Nagy, B. Csordás, V. Zsoldos-Mády, I. Pintér, V. Farkas, A. Perczel, Amino Acids 2017, 49, 223.

[14] B. Csordás, A. Nagy, V. Harmat, V. Zsoldos-Mády, I. Leveles, I. Pintér, V. Farkas, A. Perczel, Amino Acids 2016, 48, 2619.

[15] a) M.P. Kotick, R.S. Klein, K.A. Watanabe, J.J. Fox, Carbohydr. Res. 1969, 11, 369, b) E.J. Reist, R.R. Spencer, D.F. Calkins, B.R. Baker, L. Goodman, J. Org. Chem. 1951, 30, 2321.

[16] a) C. Vogel, P.J.J. Gries, Carbohydr. Chem. 1994, 13, 37. b) T. Naka, T. Hashizume, Arg. Biol. Chem. 1970, 34, 1855.

[17] a) J.J. Fox, Y. Kuwada, K.A. Watanabe, Tetrahedron Lett. 1968, 57, 6029. b) K.A. Watanabe, E.A. Falco, J.J. Fox, J. Am. Chem Soc. 1972, 94, 3273.

[18] F. Cardona, G. D’Orazio, A.M.S. Silva, F. Nicotra, B. La Ferla, Eur. J. Org. Chem. 2014, 12, 2549. 
[19] K. Michigami, M. Terauchi, M. Hayashi, Synthesis 2013, 45, 1519

[20]L. J. van den Bos, J.D.C. Codée, J.H. van Boom, H.S. Overkleeft, G.A. van der Marel, Org. Biomol. Chem. 2003, 14, 160.

[21] P. Söderman, G. Widmalm Carbohydr. Res. 1999, 316, 184.

[22] R.U. Lemieux, K. James, T.L. Nagabhushan, Y. Ito, Can. J. Chem. 1973, 51, 33.

[23] T. Mehler, W. Behnen, J. Wilken, J. Martens, Tetrahedron: Asymmetry 1994, 5, 185.

[24] L. Ying, J. Gervay-Hague, Carbohydr. Res. 2004, 339, 367.

[25] R. Johansson, B. Samuelsson, J. Chem. Soc. Perkin Trans. I. 1984, 2371.

[26] P. S. Kumar, G. D. K. Kumar, S. Baskaran, Eur. J. Org. Chem. 2008, 6063. 